\title{
MENINGKATKAN KEMAMPUAN MENULIS TEKS DESKRPSI MELALUI METODE MIND MAPPING PADA SISWA KELAS VII H SMP NEGERI 1KONAWE SELATAN
}

\author{
Yunra Nofian Nita ${ }^{1}$, Yunus $^{2}$, dan Sahlan ${ }^{3}$ \\ pbsi.fkip.uho@gmail.com
}

\author{
1, 2, 3, Jurusan Pendidikan Bahasa dan Sastra Indonesia, \\ Fakultas Keguruan dan Ilmu Pendidikan, Universitas Halu Oleo \\ Kampus Hijau Bumi Tridharma Anduonohu, Kendari, Indonesia
}

\begin{abstract}
ABSTRAK
Tujuan yang ingin dicapai dalam penelitian ini adalah untuk meningkatkan kemampuan menulis teks deskripsi dengan menggunakan metode Mind mapping pada siswa kelas VII H SMP Negeri 1 Konawe Selatan. Penelitian ini mengikuti desain PenelitianTindakan Kelas (PTK) yang bersifat kolaboratif. Penelitian ini dilaksanakan dalam dua siklus melalui langkah-langkah perencanaan, pelaksanaan tindakan, observasi, dan refleksi. Subjek penelitian ini adalah siswakelas VII H SMP Negeri 1 Konawe Selatan. Objek penelitian ini adalah peranan metode Mind mapping untuk meningkatkan kemampuan menulis teks deskripsi. Data dikumpulkan dengan teknik observasi dan tes. Data dianalisis dengan cara kualitatif dan kuantitatif. Dari hasil penelitian dapat disimpulkan bahwa penggunaan metode Mind mapping dapat meningkatkan pembelajaran keterampilan menulis teks deskripsi siswa kelas VII H SMP Negeri 1 Konawe Selatan. Hal ini dapat dilihat dari tercapainya indikator keberhasilan baik dari segi proses maupun hasil dalam penelitian ini. Rata-rata hasil observasi aktivitas guru dan aktivitas siswa meningkat pada siklus I dan siklus II. Dari segi hasil ketuntasan klasikal pada siklus I sebesar 54,55\% dan pada siklus II persentase ketuntasan klasikal sebesar 86,36\%.
\end{abstract}

Kata Kunci: kemampuan; metode mind mapping; menulis; teks deskripsi

571 | Jurnal BASTRA (Bahasa dan Sastra), Vol. 4 No.4, Edisi Oktober 2019/e-ISSN: 25033875/http://ojs.uho.ac.id/index.php/BASTRA 


\begin{abstract}
The aim to be achieved in this study is to improve the ability to write description text by using the Mind mapping method in students of class VII H Konawe Selatan 1 State Middle School. This study follows a collaborative Classroom Action Research (CAR) design. This research was conducted in two cycles through the steps of planning, implementing actions, observing, and reflecting. The subjects of this study were students of class VII H Konawe Selatan 1 State Middle School. The object of this research is the role of the Mind mapping method to improve the ability to write description text. Information was collected by observation and test techniques. Information is analyzed by qualitative and quantitative methods. From the results of the study it can be concluded that the use of the Mind mapping method can improve the learning of writing text description skills of class VII H students of Konawe Selatan 1 State Middle School. This can be seen from the achievement of indicators of success both in terms of processes and results in this study. The average observation of teacher activities and student activities increases in the first cycle and second cycle. In terms of classical completeness results in the first cycle of $54.55 \%$ and in the second cycle the percentage of classical completeness was $86.36 \%$.
\end{abstract}

Keywords: Ability, Mind Mapping method, writing description teks.

572 | Jurnal BASTRA (Bahasa dan Sastra), Vol. 4 No.4, Edisi Oktober 2019/e-ISSN: 25033875/http://ojs.uho.ac.id/index.php/BASTRA 


\section{PENDAHULUAN}

Pendidikan merupakan suatu tahapan penting yang diperlukan seseorang untuk memperoleh pengetahuan yang dapat dijadikan suatu proses perubahan tingkah laku yang nantinya dapat diterapkan dalam kehidupan sehari-hari. Menurut UU NO. 20 tahun 2003, pendidikan adalah usaha sadar dan terencana untuk mewujudkan suasana belajar dan proses pembelajaran agar peserta didik secara aktif mengembangkan potensi dirinya, masyarakat, bangsa dan Negara.

Sekolah mempunyai peranan strategis sebagai wahana transformasi pengembangan jati diri dan wawasan keunggulan bangsa. Dalam rangka memantapkan peranan sekolah dalam sistem pendidikan nasional, terdapat beberapa hal yang perlu dibenahi, salah satunya yaitu proses pembelajaran. Proses pembelajaran merupakan proses interaktif komunikasi aktif antara siswa dengan guru dalam kegiatan pembelajaran.

Belajar merupakan suatu proses perubahan tingkah laku melalui interaksi antara individu dan lingkungan di mana ia hidup. Dalam hal ini, Proses merupakan rangkaian kegiatan yang berkelanjutan, terencana, gradual, bergilir, berkeseimbangan, dan terpadu, yang secarakeseluruhanmewarnai memberikankarakteristikterhadap proses pembelajaran.

Pembelajaran Bahasa Indonesia di sekolah bertujuan untuk meningkatkan kemampuan berbahasa bagi siswa agar mereka mampu berkomunikasi, baik secara lisan maupun tulisan, dengan baik dan benar. Dalam keterampilan bahasa menulis merupakan aspek penting. Menciptakan iklim budaya menulisakan mendorong seseorang menjadi lebih aktif, lebih kreatif, dan lebih cerdas. Oleh karena itu, untuk dapat menulis dengan benar diperlukan pembiasaan diri dengan cara belajar serta berlatih secara terus-menerus dan berkesinambungan.

Tujuan menulis untuk menambah pembendaharaan kata, melatih menuangkan pikiran, pengalaman, perasaan, ataupun gagasan secara sistematis sesuai dengan kaidah kebahasaan, serta berlatih menggunakan kaidah ejaan secara benar.
Aspek dalam keterampilan berbahasa (menulis, membaca, menyimak, dan berbicara) saling berkaitan. Oleh karena itu, materi pelajaran bahasa Indonesia akan lebih efektif apabila disampaikan secara terpadu.

Penerapan kurikulum 2013 memerlukan perubahan paradig mapembelajaran, di mana peserta didik dilatih untuk belajar mengobservasi, mengajukan pertanyaan, mengumpulkan data, menganalisis (mengasosiasikan) data, dan mengkomunikasikan hasil belajar yang disebut pendekatan saintifik. Prinsip penyusunan kurikulum 2013 mengacu pada pasal 36 Undangundang No. 20 Tahun 2003 yang menyatakan bahwa penyusunan kurikulum harus memperhatikan peningkatan iman dan takwa, peningkatan akhlak mulia. Peningkatan potensi, kecerdasan, dan minat peserta didik, keragaman potensi daerah dan lingkungan, tuntunan bangunan daerah dan nasional, perkembangan ilmu pengetahuan, teknologi, dan seni, agama, dinamika perkembagan global, dan persatuan nasional dan nilai-nilai kebangsaan kurikulum 2013 menekankan demensi pedagogik modern dalam pembelajaran, yaitu pendekatan staintifik (ilmiah). Pendekatan ilmiah dalam pembelajaran meliputi menggali informasi melalui pengamatan, bertanya, percobaan, kemudian mengolah data atau informasi, menyajikan data atau informasi, dilanjutkan dengan menganalisis, menalar, kemudian menyimpulkan dan mencipta. Proses mendapatkan informasi meliputi pengamatan yang dilakukan dengan cara bertanya dengan objek yang akan diamati, setelah diketahui langkah berikutnya, menyajikan langkah tersebut melalui proses menganalisis, menalar, menyimpulkan dan menciptakan sesuatu yang baru.

Salah satu kompetensi yang harus dikuasai oleh siswa kelas VII H SMP Negeri 1 Konawe Selatan dalam kurikulum 2013 adalah melalui teks deksripsi yang terdapat pada kompetensi dasar 4.2 yaitu menyajikan data, gagasan, kesan dalam bentuk teks deskripsi tentang objek (sekolah, tempat wisata, tempat bersejarah, dan suasana pentas seni daerah) secara tulis dan lisan dengan memperhatikan struktur, kebahasaan baik secara lisan dan tulis. Berdasarkan kopetensi dasar tersebut, 
pembelajaran menulis teks deskripsi dapat dilakukan dalam dua bentuk keterampilan berbahasa, yaitu bentuk lisan dan tulisan.

Penelitian ini dilakukan di SMP Negeri 1 Konawe Selatan. Pemilihan sekolah SMP Negeri 1 Konawe Selatan didasari pertimbangan bahwa SMP Negeri 1 Konawe Selatan adalah salah satu sekolah yang sudah menerapkan kurikulum 2013 dan belum pernah dilakukan penelitian tentang menulis teks deskripsi pada penerapan 2013 sehingga, SMP Negeri 1 Konawe Selatan menarik untuk dijadikan objek penelitian. Memilih menulis teks deskripsi sebagai instrumen penelitian didasari suatu pertimbangan bahwa teks deskripsi telah diajarkan pada siswa kelas VII H SMP Negeri 1 Konawe Selatan sebagaimana tercantum dalam kurikulum 2013 kemampuan teks deskripsi secara tertulis menuntut siswa mampu menyampaikan gagasan yang dimiliki setiap tema yang diamati ke dalam bentuk tulisan deskripsi sehingga daya pikir dalam mendeskripsikan suatu objek siswa dapat berkembang.

Bedasarkan wawancara kepada Ibu Nirmati, S.Pd guru bahasa Indonesia SMP Negeri 1 Konawe Selatan terdapat kendala dalam pelaksanaan pembelajaran bahasa Indonesia berdasarkan kurikulum 2013. Ketika proses pembelajaran menulis berlangsung, kemampuan siswa dalam menulis teks deskripsi masih sangat kurang siswa kesulitan menulis paragraf sesuai struktur teks deskripsi serta mengembangkan ide-ide atau gagasannya kedalam bentuk tulisan. Hal inimenjadi salah satu penyebab rendahnya hasil belajar siswa terbukti dengan siswa yang harus melakukan perbaikan pada mata pelajaran teks deskripsi. Pemerolehan nilai terdapat 22 siswa hanya 9 siswa atau sebesar $43 \%$ yang mencapai Kriteria Ketuntasan Minimal (KKM), sedangkan 13 siswa atau sebesar 57\% tidak mencapai KKM yang ditetapkan oleh sekolah $(\mathrm{KKM}=75)$. Dengan demikian dapat dikatakan bahwa hasil belajar teks deskripsi perlu ditingkatkan dengan menggunakan metode mind mapping.

Penggunaan metode mind mapping dalam menulis teks deskripsi dipilih karena lebih sesuai diterapkan dibandingkan dengan metodemetode pembelajaran yang lainnya. Hal ini disebabkan metode mind mapping dibentuk dari gagasan-gagasan yang berbentuk peta pikiran yang dapat disesuaikan dengan struktur teks deskripsi dan kaidah kebahasaan menulis teks deskripsi yaitu, identifikasi, deskripsi bagian dan penutup. Mind Mapping adalah metode pembelajaran yang aktif digunakan untuk mengarahkan siswa pada materi yang dipelajari. Mind mapping dalam proses pembelajaran dapat melatih siswa untuk berpikir, menjelaskan sesuatu dengan sistematika yang baik, dan menggunakan logika yang tepat. Penggunaan media gambar dalam menyusun teks deskripsi secara tertulis dipilih karena menyusuaikan dengan metode yang digunakan yaitu mind mapping. Gambar dapat menjadi dasar dalam penulisan teks deskripsi. Sebab siswa dapat mendeskripsikan yang menjadi tema dalam menyusun teks deskripsi melalui gambar yang diamati.

Rumusan masalah dalam penelitian ini adalah

1. Bagaimanakah aktivitas siswa kelas VII H SMP Negeri 1 Konawe Selatan saat mengikuti proses kegiatan pembelajaran dalam meningkatkan keterampilan menulis teks deskripsi melalui metode mind mapping?

2. Bagaimanakah pengelolaan yang dilakukan guru saat melaksanakan kegiatan pembelajaran dalam keterampilan menulis teks deskripsi melalui metode mind mapping pada siswa kelas VII H SMP Negeri 1 Konawe Selatan?

3. Apakah penggunaan metode mind mapping dapat meningkatkan kemampuan menulis teks deskripsi pada siswa kelas VII H SMP Negeri 1 Konawe Selatan?

Tujuan penelitian ini adalah

1. Untuk mengetahui aktivitas siswa SMP Negeri 1 Konawe Selatan dalam meningkatkan keterampilan menulis teks deskripsi melalui metode mind mapping.

2. Untuk mengetahui pengelolaan guru saat melaksanakan kegiatan pembelajaran dalam keterampilan melalui metode mind mapping pada siswa SMP Negeri 1 Konawe Selatan melalui metode mind mapping.

3. Untuk mengetahui peningkatan kemampuan menulis teks deskripsi melalui metode mind mapping pada 
Siswa SMP Kelas VII H Negeri 1 Konawe Selatan.

Penelitian ini diharapkan dapat memberikan manfaat sebagai berikut.

1. Manfaatbagi Siswa

Memberikan pengetahuan dan pengalaman bagi Siswa dalam menulis teks deskripsi dengan menggunakan metode mind mapping sehingga dapat meningkatkan hasil belajar.

2. Manfaatbagi Guru

Sebagai bahan informasi dan pertimbangan kepada guru-guru bahasa Indonesia mengenai metode-metode pembelajaran yang dapat diterapkan pada pembelajaran bahasa Indonesia guna meningkatkan keterampilan menulis siswa.

3. Manfaat bagi Sekolah

Sebagai sumbangan pemikiran bagi sekolah yang diteliti dalam peningkatan mutu pembelajaran bahasa Indonesia khususnya dalam keterampilan menulis teks deskripsi.

4. Sebagai bahan rujukan bagi para peneliti selanjutnya untuk meningkatkan mutu pendidik.

Batasan operasional dalam penelitian ini adalah sebagai berikut.

1. Keterampilan menulis merupakan kemampuan mengungkapkan gagasan, pendapat, dan perasaan kepada pihak lain melalui bahasatulis. Pengukuran keterampilan dapat dilaksanakan pada saat berlangsungnya proses belajar mengajar yang sengaja dilakukan untuk keperluan. Salah satu pengukuran keterampilan menulis yang dilaksanakan pada saat proses belajar mengajar adalah mengarang.

2. Teks adalah bahasa yang dituturkan atau dituliskan dan bentuk-bentuk sarana lain yang digunakan untuk menyatakan apa saja yang dipikirkan.

3. Deskripsi adalah tulisan yang melukiskan sesuatu sesuai keadaan yang sebenarnya. Dengan demikian, pembaca dapat melihat atau merasakan apa yang dilukiskan oleh penulis. Tulisan deskripsi bertujuan untuk menggambarkan sesuatu yang sesuai yang dilihat pengarang.

4. Metode mindmapping adalah metode pembelajaran yang memanfaatkan otak siswa sebagai pusat untuk memperoleh informasi yang sedang dipelajari. Metode ini menuntun siswa untuk memetakan pikirannya terhadap materi yang tengah dipelajari, sehingga mudah untuk dipahami dan diingat. Mind mapping memiliki ciri khas yang sangat mencolok yaitu tampil berupa tulisan yang dilengkapi dengan simbol dan gambar dengan menggunakan berbagai warna, terutama untuk konten yang penting sehingga mudah diingat selain dari itu juga dapat menonjolkan kreativitas siswa.

\section{METODE DAN TEKNIK PENELITIAN}

JenisPenelitian

Penelitian ini dilakukan dengan menggunakan desain Penelitian Tindak Kelas (PTK). PTK merupakan salah satu upaya yang dapat dilakukan guru untuk meningkatkan kualitas peran dan tanggung jawab guru khususnya dalam pengelolaan pembelajaran. PTK adalah penelitian tindakan yang dilaksanakan dalam kelas ketika pembelajaran berlangsung PTK dilakukan dengan tujuan untuk memperbaiki atau meningkat kankualitas pembelajaran. PTK berfokus pada kelas atau pada proses pembelajaran yang terjadi di dalam kelas.

\section{Setting Penelitian}

Tempatdan Waktu Penelitian

Penelitian ini dilaksanakan di SMP Negeri 1 Konawe Selatan, Kecamatan Ranomeeto, KabupatenKonawe Selatan. Waktu penelitian dilaksanakan pada semester ganjil tahun pelajaran 2018/2019.

\section{SubjekPenelitian}

Subjek penelitianini adalah siswakelas VII H SMP Negeri 1 Konawe Selatan. Jumlah siswase banyak 22 orang yang terdiri dari 9 siswa laki-laki dan 13 siswa perempuan dengan kemampuan yang heterogen.

Faktor yang Diteliti 
Terdapat dua faktor yang diselidiki dalam penelitianini, yaitu faktor guru dan siswa. Faktor yang diselidiki dari guru adalah aktivitas pelaksanaan metode mind mapping dalam kualifikasi pembelajaran kemampuan menulis teks deskripsi sedangkan, faktor yang diselidiki dari siswa adalah kemampuan siswa dalam menulis teks deskripsi dengan menggunakan metode mind mapping. Selain itu, kepekaan atau sikap siswa dalam proses belajar mengajar siswa apakah mengalami peningkatan dalam belajar atau tidak.

ProsedurPenelitian

Penelitian ini merupakan

PenelitianTindakan Kelas (PTK) yang melakukan proses pengkajian berdaur atau bersiklus dari berbagai kegiatan. Prosedur penelitian tindakan kelas ini direncanakan dua siklus. Tiap siklus dilaksanakan sesuai dengan perubahan yang ingin dicapai, seperti apa yang telah didesain dalam faktor yang diselidiki.
Secara rinci prosedur penelitian tindakan kelas ini dijabarkan sebagai berikut.

1. Perencanaan, adapun kegiatan yang dilakukan dalam tahap ini meliputi:a) membuat skenario pembelajaran, b) membuat lembar observasi untuk melihat kondisi belajar mengajar di kelas ketika metode mind mapping diaplikasikan, c) mendesain alat evaluasi untuk melihat apakah mater imenulis teks deskripsi dalam pembelajaran bahasa Indonesia telah dikuasai oleh siswa.

2. Pelaksanaan tindakan, kegiatan yang dilaksanakan dalam tahap ini adalah melaksanakan skenario pembelajaran yang telah dibuat.

3. Observasi dan evaluasi, pada tahap ini dilaksanakan observasi terhadap pelaksanaan tindakan serta melakukan evaluasi.

4. Refleksi hasil yang diperoleh dalam tahap observasi/evaluasi dikumpulkan serta dianalisis dalam tahap ini. Kelemahankelemahan/kekurangan-kekurangan yang terjadi pada tiap siklus akan diperbaiki pada siklus selanjutnya.

\section{Soal Tes}

Soal tes berupa menulis teks deskripsi dengan media gambar menggunakan peta pikiran/mind mapping dengan memperhatikan langkah-langkah dalam penulisan teks deskripsi. Kriteria penulisan teks deskripsi dalam penelitian ini yaitu.

Tabel3.3 KriteriaPenilaianPenulisanTeksDeskripsi

\begin{tabular}{|c|c|c|}
\hline No & Aspek Paragraf Deskripsi & Skor \\
\hline & $\begin{array}{l}\text { Dimulai dengan kalimat utama tentang objek yang } \\
\text { ingin dijelaskan detailnya }\end{array}$ & $\begin{array}{l}\text { Jika } 4 \text { aspekterpenuhi }=4 \\
\text { Jika } 3 \text { aspekterpenuhi }=3 \\
\text { Jika } 2 \text { aspekterpenuhi }=2 \\
\text { Jika } 1 \text { aspekterpenuhi }=1\end{array}$ \\
\hline 2. & $\begin{array}{l}\text { Kalimat- kalimat penyusun paragrafnya merupakan } \\
\text { kalimat lengkap }\end{array}$ & $\begin{array}{l}\text { Jika } 4 \text { aspekterpenuhi }=4 \\
\text { Jika } 3 \text { aspekterpenuhi }=3 \\
\text { Jika } 2 \text { aspekterpenuhi }=2 \\
\text { Jika } 1 \text { aspekterpenuhi }=1\end{array}$ \\
\hline 3. & $\begin{array}{l}\text { Paragraf berisi kalimat- kalimat yang konsisten } \\
\text { mendeskripsikan objek }\end{array}$ & $\begin{array}{l}\text { Jika } 4 \text { aspekterpenuhi }=4 \\
\text { Jika } 3 \text { aspekterpenuhi }=3 \\
\text { Jika } 2 \text { aspekterpenuhi }=2 \\
\text { Jika } 1 \text { aspekterpenuhi }=1\end{array}$ \\
\hline
\end{tabular}

576 | Jurnal BASTRA (Bahasa dan Sastra), Vol. 4 No.4, Edisi Oktober 2019/e-ISSN: 25033875/http://ojs.uho.ac.id/index.php/BASTRA 
\begin{tabular}{|l|l}
\hline 4. & Ejaan dan tanda baca dituliskan dengan benar. \\
& \\
\hline
\end{tabular}

Analisis Data

Data tentang pelaksanaan pembelajaran pembelajaran menulis teks deskripsi menggunakan metode mind mapping dengan tes akhir siklus kemudian dianalisis dengan ketentuan :

1. Menghitungnilai rata-rata skor nilai siswa menggunakan rumus:

$$
\begin{aligned}
& \qquad M x=\frac{\sum x}{\mathrm{~N}} \\
& \text { Keterangan: } \\
& \mathrm{M} x=\text { mean yang dicari } \\
& \sum x=\text { jumlahskor yang dicapai } \\
& \mathrm{N}=\text { jumlahkeseluruhanresponden }
\end{aligned}
$$

2. Untuk mengeta hui nilai ketuntasan belajar individual, dengan menggunakan rumus:

Nilai akhir $=\underline{\text { Skor pemerolehan siswa }} \times 100 \%$ Skor total

3. Menentukan persentase ketuntasan belajar secara klasikal dengan menggunakan rumus:

$\mathrm{KK}=\underline{\text { Jumlah nilai yang diperoleh siswa nilai } \geq}$ 75x $100 \%$

Jumlah siswa yang mengikutites

Keterangan :

$\mathrm{KK}=$ Ketuntasan Klasikal

Indikator keberhasilan

Indikator keberhasilan dalam penelitian ini terdiri dari beberapa indikator keterlaksanaan skenario pembelajaran dan indikator peningkatan hasil belajar siswa. Adapun perentasi kedua indikator tersebut adalah sebagai berikut.

a. Pembelajaran dikatakan berhasil jika minimal $85 \%$ skenario pembelajaran terlaksana, baik yang dilaksanakan oleh guru maupun siswa.

b. Hasil belajar menulis teks deskripsi dikatakan meningkat apabila ketuntasan secara klasikal minimal $85 \%$ siswa yang telah mencapainilai KKM yaitu
Jika 4 aspekterpenuhi $=4$

Jika 3 aspekterpenuhi $=3$

Jika 2 aspekterpenuhi $=2$

Jika 1 aspekterpenuhi $=1$

75, yang telah ditetapkan oleh sekolah untuk mata pelajaran bahasa Indonesia.

\section{HASIL DAN PEMBAHASAN}

Penelitian tindakan kelas ini terdiri atas dua siklus. Tiap siklus terdiri atas dua pertemuan yang dilaksanakan sesuai dengan prosedur penelitian. Dalam penelitian ini guru menggunakan metode mind mapping dalampembelajaran menulis teks deskripsi sebagai solusi untuk meningkatkan kemampuan menulis siswa kelas VII H SMP Negeri 1 Konawe Selatan.Aktivitas siswa kelas VII H SMP Negeri 1 Konawe Selatan saat mengikuti proses kegiatan pembelajaran menulis teks deskripsi, kemampuan awal menunjukan bahwa masih ada siswa yang belum mencapai kriteria keberhasilan yang ditentukan, dibuktikan dengan siswa yang harusmelakukanperbaikan pada matapelajaranteksdeskripsi, terdapat 22 siswahanya 9 siswaatausebesar $43 \%$ yang mencapaikriteriaketuntasan minimal. Berdasarkan data tersebut peneliti dan guru kolaborator melaksanakan tindakan siklus I terdiri dari 2 pertemuan. Setelah dilaksanakan tindakan siklus I diketahui hasil kemampuan menulis teks deskripsi pada siswa kelas VII H SMP Negeri 1 Konawe Selatan megalami peningkatan dibandingkan hasil kemampuan awal,walaupun peningkatan tersebut belum seluruhnya mencapai kriteria keberhasilan yang ditentukan, pencapaian pada siklus I yaitu sebesar $54,55 \%$.

Data yang diperoleh dari pelaksanaan tindakan siklus I setelah dilakukan analisis dan evaluasi dapat disimpulkan hasil yang diperoleh belum optimal. Oleh karena itu peneliti dan guru sepakat untuk melakukan siklus II. Pelaksanakan siklus II dilakukan sebanyak 2 kali pertemuan dengan materi teks deskripsi menggunakan metode mind mapping. Hasil tindakan siklus II kemampuan siswa dalam menulis teks deskripsi mengalami peningkatan dibandingkan pada tindakan siklus I. Pada tindakan siklus II hasil tes siswa mengalami peningkatan persentase sebesar 86,36 . yang mendapat nilai $\geq 75$ sudah mencapai $85 \%$ yakni $86,36 \%$ atau 19 siswa, sedangkan siswa yang belum mencapai indikator 
keberhasilan memperoleh nilai $<75$ sebesar $13,64 \%$ atau sebanyak 3 siswa, dengan meningkatnya nilai yang diperoleh oleh siswa yang pada persentase siklus II maka penelitian ini berhenti pada siklus II.

Selain itu, hasil observasi yang dilakukan selama penelitian menunjukan bahwa sebelum diberi perlakuan, siswa kurang bersemangat dalam mengikuti pelajaran. Pada kegiatan menulis teks deskripsi ada beberapa siswa tampak kebingungan karena tidak mengetahui apa yang seharusnya ditulis. Namun setelah diberikan tindakan siswa sangat antusias dalam mengajukan pertanyaan, menjawab pertanyaan yang diberikan oleh guru. Siswa juga mulai aktif dalam mengikuti pembelajaran, mampu memahami materi yang sedang dipelajari, selain itu siswa mampu menulis karangan deskripsi dengan memperhatikan isi teks deskripsi. Dengan tercapainya kriteria ketuntasan minimal (KKM) pada siswa kelas VII H SMP Negeri 1 Konawe Selatan. Maka pembelajaran menulis teks deskripsi dengan menggunakan metode mind mappingini dapat dikatakan berhasil.Kedua siklus megalami peningkatan berdasarkan hasil pembelajaran menulis teks deskripsi yang mencapai kriteria ketuntasan minimal (KKM). Penelitian ini, meningkatkan kemampuan menulis teks deskripsi yaitu mendeskripsikan atau menggambarkan sebuah gambar yang menjadi tema penulisan dengan memperhatikan ciri-ciri dan struktur dalam penulisan teks deskripsi dengan menggunakan metode mind mapingdapat berjalan dengan baik. Peningkatan kemampuan menulis teks deskripsi siswa dari tahap siklus I hingga siklus II diukur berdasarkan hasil pembelajaran, yakni nilai menulis siswa. Dimana, persentase ketuntasan belajar secara klasikal telah tercapai yaitu $85 \%$ berdasarkan hasil evaluasi dari siklus I hingga siklus II terjadi peningkatan.

\section{Kesimpulan dan Saran}

Berdasarkan hasil analisis data dan pembahasan hasil penelitian tindakan kelas dengan menggunakan metode mind mappingdalam pembelajaran menulis teks deskripsi pada siswa kelas VII H SMP Negeri 1 Konawe Selatan dapat disimpulkan bahwa dengan menerapkan metode mind mapping dapat meningkatkan hasil belajar atau kemampuan menulis teks deskripsi siswa kelas VII H SMP
Negeri 1 Konawe Selatan. Hal ini dapat dilihat dari persentase hasil tes tindakan siklus I yaitu dari 22 siswa yang mengikuti tes, sebanyak 12 siswa atau sebesar $54,55 \%$ yang mendapat nilai $\geq 75$. Sedangkan pada siklus II mengalami peningkatan yaitu dengan persentase 86,36\% atau sebanyak 19 siswa mendapat nilai $\geq 75$, sehingga penelitian ini diberhentikan hanya pada siklus II karena indikator keberhasilan penelitian telah tercapai yaitu $85 \%$.

\section{DAFTAR PUSTAKA}

Arikunto, $\quad$ Suharsimi,dkk. 2012. PenelitianTindakan Kelas. Jakarta: PT BumiAksara.

Abigail W, Monica.2015. Belajar Menulis. Surabaya: PT Jepe Press Media Utama.

Abdullah Sani, Ridwan. 2015. Pembelajaran Saintifik untuk ImplementasiKurikulum 2013. Jakarta: PT BumiAksara.

Buzan, Tony. 2012. Buku Pintar Mind Mapping. Jakarta: PT GramediaPustaka

Dalman. 2016. Keterampilan Menulis. Jakarta: PT Raja Grafindo Persada.

Finoza, Lamuddin. 1993. Komposisi Bahasa Indonesia. Jakarta: Diksi Insan Mulia.

Wassid, Iskandar dan Dadang Sunendar. 2009. Strategi Pembelajaran Bahasa. Bandung: PT Remaja RosdaKarya.

Keraf, Gorys. 2017. Eksposisi dan Deskripsi. Flores: Nusa Indah.

Mahsun. 2014.Teks dalam Pembelajaran Bahasa Indonesia Kurikulum 2013. Jakarta: PT Raja Grafindo Persada.

MuhibbinSyah. 2014. Psikologi Pendidikan. Bandung: PT RemajaRosdakarya. Jakarta: PT RajaGrafindoPersada.

Mahmudi. 2011. Penuntun Penulisan KaranganIlmiah. Yogyakarta: AswajaPressindo. 
Suparno dan Mohamad Yunus. 2008. Keterampilan Dasar Menulis. Jakarta: Universitas Terbuka.

Sanjaya,Wina. 2009. Penelitian Tindakan Kelas. Jakarta: Prenada Media Grup.

Sitohang, Muston N. M, dkk. 2015. Laporan Hasil Penelitian Tim Kebahasaan: Sikap Guru Bahsa SMTP dan SMTA terhadap Bahasa Indonesia di Kota Kuala Kurun Kabupaten Gunung Mas. Kalimantan Tengah: Balai Bahasa Provinsi Kalimantan Tengah Badan Pengembangan dan Pembinaan Bahasa Kementrian Pendidikan dan Kebudayaan 2015.

Soebachman, Adiba A. 2016. Mahir Menulisdalam 4 Hari. Yogyakarta: KaunaPustaka Rt. 01 Tanaman.

Swadarma, Doni. 2013. Penerepan Mind Mapping dalamKurikulumPembelajaran. Jakarta: PT Elex Media Komputindo Utama.

Tarigan, Henry Guntur. 2013. Menulis Sebagai Keterampilan Berbahasa. Bandung: CV Angkasa. 